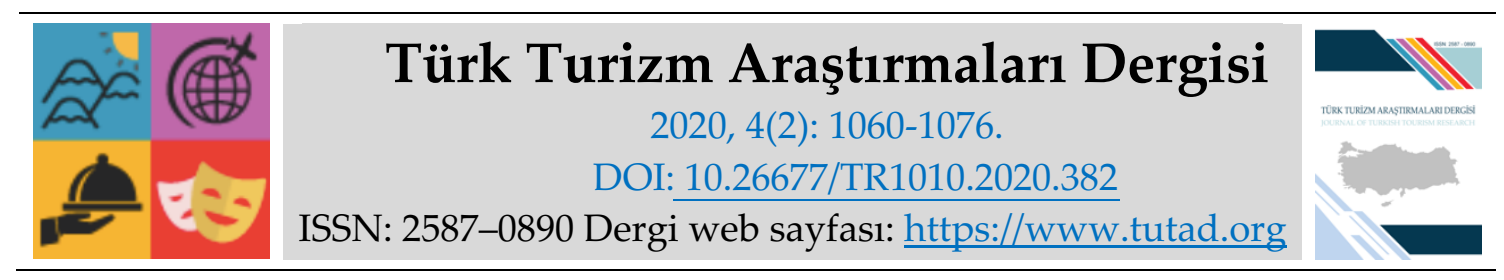

ARAȘTIRMA MAKALESI

\title{
Turist Tipolojileri ve Bilgi Arama Davranışı Üzerine Bir Araştırma
}

Doç. Dr. Nurettin AYAZ, Karabük Üniversitesi, Safranbolu Turizm Fakültesi, Karabük, e-posta: nurettinayaz@karabuk.edu.tr ORCID: https://orcid.org/0000-0003-2117-2015

Fatma GÖKMEN, Karabük Üniversitesi, Sosyal Bilimler Enstitüsü, Karabük, e-posta: fatmagokmen@hotmail.com.tr ORCID: https://orcid.org/0000-0003-1346-6590

Öz

Turizmde özne konumunda olan ve sektörün varlık nedenini oluşturan turistlere yönelik araştırmaların önemi oldukça büyüktür. Özellikle tüketici davranışı kapsamında turistlere yönelik araştırmalar, mevcut turistlerin memnuniyetlerinin artırılması ve potansiyel turistlerin kazanılmasında oldukça yardımcıdır. Bu araştırmada farklı tipolojilere sahip bulunan turistlerin tüketici davranışı bağlamında seyahat kararları öncesi bilgi araştırmalarına odaklanılmış ve turist tipolojileri ile bilgi araştırma davranışı arasında anlamlı bir ilişkinin bulunup, bulunmadığı test edilmesi amaçlanmıştır. Bu amaç doğrultusunda Karabük iline bağlı olan Safranbolu ilçesine Mayıs-Eylül 2016 döneminde ziyaret gerçekleştiren 432 yerli turiste anket uygulanmıştır. Anket verilerinin analizi sonucunda Safranbolu ilçesine ziyaret gerçekleştiren yerli turistlerin tipolojilerinin araştırmacı turist, organize kitle turist ve maceracı turist olmak üzere üç boyutta şekillendiği tespit edilmiştir. Turistlerin seyahat öncesi bilgi araştırma sürecinde destinasyon genel özellikleri, ulaşım-konaklama imkanları, seyahat güzergahları, sağlık-güvenlik imkanları ve eğlence imkanlarına yönelik bilgi araştırmasına yöneldikleri belirlenmiştir. Araştırma sonucunda görülmüştür ki turist tipolojisi ile bilgi araştırma davranışı arasında düşük düzeyde bir pozitif bir ilişki $(\mathrm{r}=0,281)$ bulunmaktadır. Yerli turistlerin bilgi araştırma davranışında öncelikleri ulaşım ve konaklama imkanları, seyahat güzergahları, sağlık ve güvenlik imkanları, eğlence imkanları ve destinasyon genel özellikleri oluşturmaktadır. Ayrıca araştırmacı turistlerin organize kitle turistler ve maceracı turistlere göre daha fazla bilgi araştırması yaptıkları tespit edilmiştir.

Anahtar Kelimeler: Turistik Ürün, Turist Tipolojisi, Satın Alma Kararı, Bilgi Araştırması, Safranbolu.

Makale Gönderme Tarihi: 08.01.2020

Makale Kabul Tarihi: 10.04 .2020

\section{Önerilen Atıf:}

Ayaz, N. ve Gökmen, F. (2020). Turist Tipolojileri ve Bilgi Arama Davranışı Üzerine Bir Araştırma, Türk Turizm Araştırmaları Dergisi, 4(2): 1060-1076.

(C) 2020 Türk Turizm Araştırmaları Dergisi. 


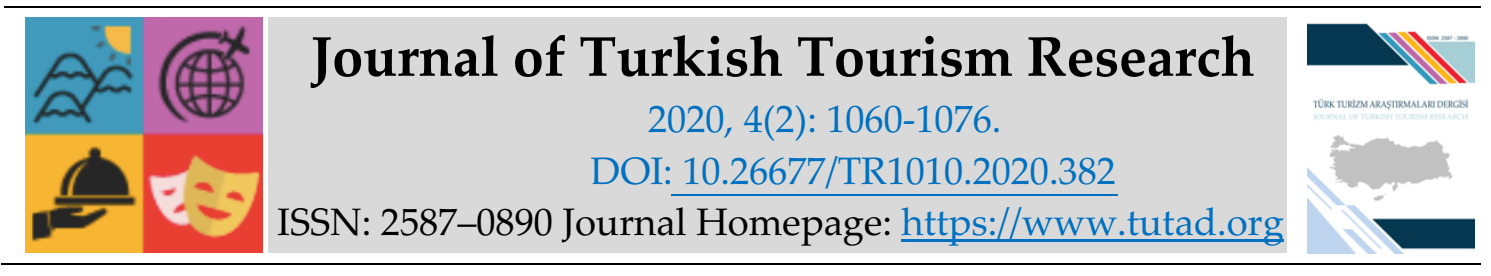

RESEARCH PAPER

\title{
A Research on Tourist Typology and Information Search Behavior
}

Associate Prof. Dr. Nurettin AYAZ, Karabük University, Safranbolu Tourism Faculty, Karabük, e-mail: nurettinayaz@karabuk.edu.tr

ORCID: https://orcid.org/0000-0003-2117-2015

Fatma GÖKMEN, Karabük University, Social Sciences Institute, Karabük, e-mail: fatmagokmen@hotmail.com.tr ORCID: https://orcid.org/0000-0003-1346-6590

\begin{abstract}
The importance of the research for tourists who are the subject of tourism and the tourists who are the reason for the existence of the sector is very important. Especially in the context of consumer behavior, researches for tourists are very helpful in increasing the satisfaction of current tourists and gaining potential tourists. This study is aimed to determine whether there is a meaningful relationship between tourist typologies and information research behavior before the travel decisions in the context of consumer behavior of tourists with different typologies. For this purpose, 432 domestic tourists visited the Safranbolu district of Karabük province in the May-September 2016 period were surveyed. As a result of the analysis of the survey data, it was determined that the typologies of the domestic tourists who visited Safranbolu district were shaped in three dimensions as researchers' tourists, organized mass tourists and adventurous tourists. It was determined that the tourists were interested in information research in general information about the destination, transportation accommodation facilities, travel routes, health safety facilities and entertainment facilities during the information research process before the travel. As a result of the research, it was determined that there is a low positive relationship $(\mathrm{r}=0,281)$ between tourist typology and information research behavior. Priorities of domestic tourists in information research behavior were composed of transportation and accommodation facilities, travel routes, health and safety facilities, recreational facilities and the general characteristics of the destination. It was also found that the researcher tourists do more research than the organized mass tourists and adventurous tourists.
\end{abstract}

Keywords: Touristic Product, Tourist Typology, Purchasing Decision Making, Information Search, Safranbolu.

Received: 08.01 .2020

Accepted: 10.04 .2020

\section{Suggested Citation:}

Ayaz, N. and Gökmen, F. (2020). A Research on Tourist Typology and Information Search Behavior, Journal of Turkish Tourism Research, 4(2): 1060-1076.

(C) 2020 Türk Turizm Araştırmaları Dergisi. 


\section{Gíriş}

İşletmelerde iyi bir pazarlama perspektifi oluşturulması için temel özellikler; müşteri segmentleri, rakipler ve genel iş ortamı arasındaki eğilimleri izleme ve yorumlama, mevcut ve potansiyel müşteriler ile ilgili detaylı bilgilere ulaşma, karar vermede araştırma ve bilgiye güvenme, müşterilerin artan beklentilerini ve memnuniyetini çerçevesinde ürün kalitesinde ve işletme operasyonlarında iyileştirme ve geleceğe dönük yenilikleri izleme ile ilişkilendirilmektedir (Middleton ve Hawkins, 1998).

Pazarlama sürecinin merkezinde yer alan müşteri odaklı hareket etme eğilimi kapsamında bireylerin, grupların veya kuruluşların ihtiyaçlarını karşılamak için ürünleri, hizmetleri, deneyimleri veya fikirleri seçmek, güvence altına almak ve elden çıkarmak için kullandığ süreçlerle ilgilenen tüketici davranışı (Kuester, 2012), turizm sektörü için de irdelenmesi gereken önemli bir konudur.

Turizmde tüketici davranışı; seyahat öncesi, seyahat esnası ve seyahat sonrası olarak değerlendirmeleri içeren bir süreçtir. Turistleri anlama, istek ve ihtiyaçlarını tanıma bağlamında bu süreçlerin ayrı ayrı irdelenmesi önemli bir gerekliliktir. Bununla birlikte bu süreçler içerisinde seyahat öncesi karar süreci, tüketicilerin en çok karmaşa yaşadıkları evrelerden biridir. Bu sürecin anlaşılmasına yönelik bilimsel çalışmalar, önem arz etmektedir.

$\mathrm{Bu}$ araştırmada kültürel turistlerin tipolojilerine göre seyahat kararları öncesi bilgi araştırmalarına odaklanılmakta, bilgi araştırmasının satın alma kararlarına olan etkisi irdelenmekte ve turistik ürün talebinde bulunacak turistlerin seyahat öncesi kararlarını vermeden önce yaptıkları/yapacakları araştırmaların satın alma eylemlerine nasıl etki ettiği/edeceği incelenmektedir. Dünya Miras Listesi içerisinde yer alan ve kültürel bir destinasyon olarak tanınan Safranbolu ilçesini ziyaret eden yerli turistlerin seyahat öncesi karar sürecine yönelik bir öngörü oluşturulması hedeflenmektedir. Araştırma Safranbolu özelinde kültürel turistleri tanıma ve beklenti önceliklerini belirme yönüyle önem arz etmektedir. Ayrıca iç turizmi, geliştirme ve kültür turizmini anlama düzeyinde literatür zenginliği oluşturabilecektir. Araştırmanın ortaya koyacağı sonuçlar ile pazarlama yöneticilerine, işletmelere ve akademisyenlere tüketicilerin hangi bilgi kaynakları ve satın alma öncesi kararları konusunda faydalı olması beklenmektedir.

\section{LITERARÜR İNCELEMESI}

Turistik ürün, herhangi bir turist ziyareti göz önünde bulundurularak bir destinasyondaki etkinliğe dayalı maddi ve manevi bileşenlerden oluşan bir paket olarak tanımlanmakta ve ana unsurları; destinasyonda var olan turistik çevre ve yerler, tesisler ve hizmetler, destinasyonun imajı, ulaşılabilirliği ve tüm bunların turiste olan maliyeti şeklinde sınıflandırılmaktadır (Middleton ve Hawkins, 1998). Turistik ürün; tüketicilerin dikkatini çekmek veya kullanmalarını sağlamak için turizm pazarına sürülmüş, turistlerin gereksinimlerini karşılama olasılığı olan (Kotler, 2000) fiziksel nesneler, hizmetler, aktiviteler ve yerlerin bütünü (Sönmez, 2014) olarak da literatürde kendisine yer bulmaktadır.

Turistik ürün, bir hizmetler bütünü olup, farklı hizmet sağlayıcıları tarafından sağlanan hizmetlere yönelik müşterilerin memnuniyetine odaklıdır (PSHE, 2009). Turistik ürün, çok kapsamlı gereksinimleri karşılama maksadıyla turizm işletmeleri tarafından bir araya getirilmiş mal ve hizmetler bütünü olarak doğal, toplumsal, siyasal ve psikolojik verilerden oluşur. Turistik üründe ortak nokta; turistin tüketim konusu içerisinde yer alan mal ve hizmetlerin turiste fayda sağlayacak şekilde ürün kavramına dahil edilmesidir (Yağcl, 2007). 
Turistik ürün, tüketicilerin öznel algılarına dayandığ 1 için bileşenlerinin net olarak belirlenmesi güçtür (Orel ve Memmedov, 2003). Bununla birlikte turistin yaşadığı yerden ayrılıp tekrar geri dönene kadar geçirdiği süre içinde yararlandığı bütün mal ve hizmetler (Akk1liç, 2002; Şimşek, 2008; Sönmez, 2014) ile yaşadıkları tüm anılar turistik ürün kapsamındadır (Paksoy, 1994; Şenel, 2001).

Turistik ürün, farklı niteliklere sahip unsurlardan oluşan karmaşık bir üretimdir. Bir aş̧̧ının yaptığı yemekler, bir barmenin hazırladığı içecekler, satışa sunulan bir oda, turistik yerin sahip olduğu doğal güzellikler, bölgedeki yaşam tarzı bütünüyle turistik ürünü oluşturan unsurlardır (Şimşek, 2008; Paksoy, 1994). Bu bağlamda yapılacak olan pazarlama planlamasında, turistik potansiyeli olan bölgenin doğal güzelliklerinin yanında, konaklama işletmelerini, restoranlarını, ulaşım gibi hizmetlerini de kapsadığına dikkat edilmelidir (Sönmez, 2014).

Turizm sektöründe pazarlama yöneticileri, turizmin öznesi konumunda olan turistler hakkında bilgi sahibi olması; destinasyona yönelik stratejiler oluşturma, destinasyonun çekiciliğini artırma ve gelişimine katkı sağlamada önemli hale gelmiştir (Pekyaman, 2008). Turizmde stratejik planlamalar, çoğunlukla turistler üzerine kuruludur. Bu anlamda turizm olayının varlık nedenini oluşturan biyolojik, psikolojik ve sosyolojik özellikleri bulunan turistlerin kim olduğunun ve nasıl hareket ettiklerinin incelenmesi önemli bir gerekliliktir. Turizm sektöründe rakiplere üstünlük sağlamada turistler hakkında bilgi sahip olmak önemli bir üstünlüktür (Kılıçbey, 2017). Özellikle bir destinasyonun mekânsal tasarımı başta olmak üzere rasyonel planlama sürecinde etkin turizm politikasının benimsenmesinde katkı sağlamada ve turizm planlamasında turist tipolojilerine yönelik çalışmalar çok önemlidir (Coccosss ve Constantoglou, 2006). Bu kapsamda turistleri tanımak ve sınıflandırmak için yıllar içinde çeşitli tipolojiler geliştirilmiştir. Bu tipolojiler farklı turizm türlerine göre şekillendirilmiştir.

Sosyolog Erik Cohen, 1972 yılında yazdığı "Uluslararası Turizm Sosyolojisine Doğru" adlı makalesi ile farklı türden turistlerin olduğunu öne süren ilk kişi olmuştur (Lowry, 2017). Hvenegaard (2002), eko turizm için turistleri; araştırmacı tabanlı, katılımcı tabanlı, etkinlik tabanlı ve motivasyona dayalı olmak üzere dört tipe ayırmıştır. Günümüzde ise turist tipolojileri çoğunlukla turistin amaçlarına dayandırılmakta ve iki ana gruba ayrıldığı düşünülmektedir. Bu gruplar "sunlust" ve "wanderlust" olarak adlandırılmaktadır. Bunlardan ilki "dinlenme ve rahatlama" için yapılan seyahate çıkanlar, ikincisi ise "öğrenme arzusu" ile seyahate çıkanlarla ilişkilendirilmektedir (Dey ve Sarma, 2006: 31).

Turist tipolojilerin belirlenmesinde genel olarak üç temel bileşenin (demografik, sosyoekonomik ve psikografik) kullanılması önerilmektedir. Bununla birlikte demografik ve sosyoekonomik özelliklerin turist davranışlarının zayıf bir göstergesi olduğu düşünülmekte olup psikografik değişkenine yönelme öne çıkartılmaktadır. Psikografik değişkenler içinse tutum, motivasyon, inançlar, değerler, motifler, ihtiyaçlar ve arzuların kullanılmasının gerekliliğine vurgu yapılmaktadır (Marwijk ve Taczanowska, 2006).

Tüketicilerin satın alma kararı birçok faktörden etkilenir. Tüketicilerin satın almayı düşündükleri herhangi bir ürün ya da hizmetin öneminin kişiden kişiye farklılık göstermesi bu durumun birincil nedeni oluşturmakla birlikte tüketicilerin satın alma öncesi araştırma yapma eğilim süreci, pazarlamacıların odaklanması gereken bir alandır (www.mbaknol.com).

Potansiyel tüketicilerin bir ihtiyaç ortaya çıtıktan sonra bu ihtiyacı karşılayacak alternatif ürün, hizmet, deneyim ve satış noktalarını tanımlamaya ve değerlendirmeye yardımcı olacak bilgileri; aile, arkadaşlar, arama motorları, web incelemeleri, kişisel gözlem, tüketici raporları, satış görevlileri, vb. herhangi bir sayıda kaynaktan edinilebilmekle birlikte, birden çok seçenek karşısında kaldıkları zaman kendileri için en uygun olan ürün ya da hizmeti seçebilmek ve en doğru kararı verebilmede ürün veya hizmetin ilk kez satın alınması, çok uzun bir zaman önce 
kullanılmış olması ya da benzer özelliklere sahip birçok ürün ya da hizmetin mevcudiyeti gibi durumlarda fazla bilgi araştırması yapmadan satın alma eylemini gerçekleştirdikleri yönündedir (Yilmaz, 2010; https://courses.lumenlearning.com). Bununla birlikte Hawkins vd. (2013), tüketicilere sunulan bilgi kaynakları; geçmiş aramaların belleği (kişisel deneyimler, düşük katılımlı öğrenme), kişisel kaynaklar (arkadaşlar, aile ve diğerleri), bağımsız kaynaklar (dergiler, tüketici grupları, devlet kurumları), pazarlama kaynakları (satış elemanı, internet siteleri, reklamcılık) ve dışsal kaynaklar (inceleme veya ürün deneme) şeklinde beş gruba ayrılabildiğini belirtmektedir.

Turizmde belirli bir ürünü satın almayı etkileyen faktörler; motive edici faktörler (turisti belirli bir ürünü satın almak istemeye iten faktörler) ve belirleyiciler (turistlerin istedikleri ürünü ne kadar satın alabileceklerini belirleyen faktörler) olarak gösterilmektedir. Bununla birlikte bir tüketicinin bir satın alma kararı verirken ihtiyacın ortaya çıkması, bilgi toplama, alternatiflerin değerlendirilmesi, satın alma kararı ve satın alma sonrası davranış olmak üzere beş aşamalı bir süreçten geçtiği, sürecin başlangıcında potansiyel bir alıcı olan tüketicinin süreç içerisinde herhangi bir aşamada geri çekilebildiğine dikkat çekilmektedir (https://courses.lumenlearning.com). Ayrıca, seyahat etmek ve tatile çıkmak, sosyal bir faaliyet olarak potansiyel turistlerin karar verme sürecinde sıkça bilgi araştırmasına yöneldikleri alanlar olarak gösterilmekte ve deneyime sahip olan tüketicilerin bu aşamaları hızlıca geçtikleri ve deneyime sahip olmayan tüketicilerin ise titizlikle hareket ettikleri yönündedir. Ayrıca, turistlerin bilgi toplama adına faydalandıkları iki önemli kaynak; önceki deneyimler neticesinde akılda kalan bilgiler ve reklamlar, turizm dergileri, seyahat acentaları, arkadaşlar gibi çevresel unsurlardan sağlandığı şeklindedir (Hayta, 2008).

Bilgi arama davranışı bireysel bir faaliyet olarak, etkili ve kaliteli bir problem çözme sürecinde önemli yer tutan bir aşamadır. Birey davranışlarının biyolojik, psikolojik ve sosyolojik olaylar ve nedenler çerçevesinde şekillenmesi, bu aşamayı daha da önemli hale getirmektedir. Bilgi arama davranışı, insanın bilgiye olan ihtiyacın fark etmesi ile başlayarak yeterli bilgiyi toplayı kullanması aşamasına kadar devam eden bir süreç olarak tanımlanmaktadır. Bununla birlikte bilgi arama davranışı, insanların bazı ihtiyaçlarını giderme ve amaçlarına ulaşabilmeleri için başvurdukları bir yöntemdir (Baysal ve Tekarslan, 2004; Wilson, 2000).

Bilgi arama, bilgi kaynakları içerisinden gereksinimlere en uygun olan bilginin tanımlanması ve seçilmesi işlemidir. Bilgi arama davranışı ise ortaya çıkan bilgi gereksiniminin karşılanması için yapılan bireysel bir etkinlik olarak ifade edilmektedir. İnsanların karar vermesi, ortaya çıkan problemin çözülmesi ya da kaynakların taranması gibi süreçleri kapsamaktadır. Başlı başına bir işlem olan bilgi arama davranışı elde edilen sonuçlara ve farklı zaman dilimlerine bağlı olarak bilginin kabul edilmesi ve reddedilmesi ile ilgili yöntem ve ölçütlerden meydana gelen dinamik bir süreçtir (Rouse ve Rouse, 1984). Birbiriyle iç içe geçmiş kavramlar olan bilgi gereksinimi ve bilgi arama davranışı aynı amaca sahip birbirini tamamlayan kavramlardır. Bu bağlamda bilgi gereksinimi sonucunda bilgi arama davranışının oluştuğu gibi, bilgi gereksiniminin giderilmesi ile de yeni bilgi gereksinimlerinin ortaya çıkması muhtemeldir (Uçak, 1997). Bilgi arama davranışı var olan bilgideki herhangi bir eksiklik ya da sıra dişılık ile başlayarak eksikliğin giderilmesi ve konunun anlaşılması tamamlanana kadar devam etmektedir. Bireylerin kendilerine özgü psikolojileri, kişilik özellikleri ve birikimleri edindikleri bilgiyi farklı olarak değerlendirmelerine neden olmaktadır (Westbrook, 1993).

Bir süreç olan bilgi arama davranışı; çözüm odaklı ve belirsizlik içerisinde sentezlenerek anlam bulmaktadır (Marchionini, 1989; Case, 2007; Dervin ve Nilan, 1986; Kuhlthau, 1993). Ayrica bireylerin bilgi toplamak için birbirleriyle etkileşime geçtiği bir süreç olarak da nitelendirilen bu davranışı ilk olarak belirsizlik unsuru tetiklemekte ve tatminin gerçekleştirildiği an belirsizliğin ortadan kaldırıldığını ifade etmektedir (Todd, 2003). Bireylerin ihtiyaçlarını gidererek tatmin 
Türk Turizm Araştırmaları Dergisi, 4(2): 1060-1076.

evresine ulaşması ile son bulan belirsizlik süreci içerisinde var olan tüm etkileşimsel süreç bilgi arama davranışını betimlemektedir (Soylu, 2016).

İhtiyaç için uyarılmış bir tüketicinin bilgi araştırması kapsamında bilgi edinme kaynakları; kişisel kaynaklar (aile, arkadaşlar, komşular vb.), ticari kaynaklar (reklamlar, satış personeli, aracı işletmeler vb.) ve kamu kaynakları (broşür, dergi, gazete vb.) etkili olduğu belirtilmektedir. Tüketicinin satın alacağı üründe riski azaltabilmek için güvendiği kişilerden bilgi alma, ün yapmış bir işletmeye güvenme, garanti arama, satın alma öncesi ürünü deneme ve interneti kullanarak ürünleri karşılaştırma yapmayı tercih ettiği yönündedir (Uygur, 2007: 190).

Tüketicinin bir ihtiyaç kapsamında bilgi arama davranışının önce içsel olarak (uzun süreli düşünme) çözmeye çalıştıkları gerekli çözümü bulamadıklarında dışsal aramaya yöneldikleri şeklindedir. Turizmde bilgi arama gereksinimleri; çekim yerleri, oteller, sayfiyeler, ulaşım araçları, oto kiralama, paket turlar ve yiyecek ve içeceklerde ortaya çıkabilmektedir. Bununla birlikte satın alma kararında genel ölçütler; maliyet (fiyat, kalite, ödünleme, ek hizmet, harcanan çaba, uzaklık, maliyet üstünlüğü), başarma (saygınlık, etkinlik, güvenirlik, yeterlilik, ekonomiklik, uzun süreklilik), uygunluk-kolaylıkla (ürün çeşitliği, çok kullanışlılık) ilişkilendirilmektedir (Rızaoğlu, 2007).

Dünya turizm pazarında yeni destinasyonlar ve artan ürün sayısı rekabeti keskinleştirmektedir. Bu rekabet ortamında ulusal veya bölgesel bazda pazar paylarını korumak isteyen destinasyonlar için çağdaş teknolojilerden yararlanarak sürekli çaba harcanması önemli bir gerekliliktir (Akay vd., 2014). Turist tipolojilerin tüketici davranışı kapsamında irdelenmesi halen pazarlamacı ve araştırmacılar için ilgi çekici bir alandır. Bu kapsamda turistlerin bilgi arama davranışının incelendiği bu çalışma, literatür için önemli bir zenginlik oluşturabilecektir.

\section{YÖNTEM}

$\mathrm{Bu}$ araştırma, yerli turistlerin seyahat öncesi bilgi araştırma durumları ile tipolojileri arasındaki ilişkinin ortaya çıkarılmasına yönelik betimsel ve nicel bir çalışmadır. Çalışma, "var olan bir durumu olduğu şekliyle tespit etmeyi" öngören tarama modeli (Karasar, 1995) üzerine kurgulanmıştır.

\section{Araştırmanın Amacı ve Önemi}

Turistin yaşadığı yerden ayrılıp tekrar geri dönene kadar geçirdiği süre içinde yararlandığı bütün mal ve hizmetlerle ilişkilendirilen (Akk1liç, 2002; Orel ve Memmedov, 2003; Paksoy, 1994, Sönmez, 2014; Şenel, 2001; Şimşek, 2008) turistik ürün kapsamında turistlerin ihtiyaçlarının tam olarak karşılanabilmesi ve turistik tüketim kapsamında ilgili mal ve hizmetlerin turiste fayda sağlayacak şekilde sunulması önemli bir gerekliliktir (Yağcı, 2007). Bu gereklilik kapsamında turistlerin seyahat öncesi davranışlarının (seyahat çıkma isteği, bilgi arama, alternatif seçeneklerin değerlendirilmesi, karar verme ve seyahat hazırlıkları) öğrenilmesi öne çıkartılmaktadır (Demir ve Kozak, 2011). Seyahat kararı öncesi bilgi verici tanıtımların potansiyel turistleri bilinmeyen destinasyonlara yönlendirmede ve ziyaret niyetini artırmada etkili olduğuna dikkat çekilmektedir (Hui Lin vd., 2016).

Bu araştırmanın amacı Safranbolu destinasyonu özelinde kültürel turistleri tipolojilerine göre tanıma, beklenti önceliklerini öğrenme ve destinasyona ziyaret gerçekleştiren yerli turistlerin seyahat öncesi bilgi araştırmalarına yönelik bir öngörü oluşturmaktır. Ayrıca çalışmanın iç turizmi geliştirme ve kültür turizmini anlama düzeyinde literatür zenginliği oluşturması beklenmektedir. 


\section{Araştırmanın Problemi ve Hipotez}

"Yerli turistlerin tipolojileri ve seyahatleri öncesinde bilgi araştırma davranışları arasındaki ilişki" bu çalışmanın araştırma problemi olup, bu problem bağlamında aşağıdaki hipotezin test edilmesi öngörülmüştür:

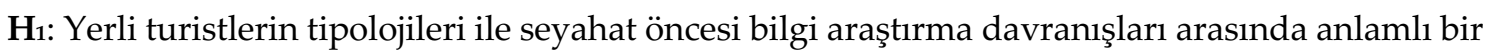
ilişki vardır.

\section{Evren, Örneklem ve Verilerin Toplanması}

$\mathrm{Bu}$ araştırma için evren Karabük ili içerisinde bulunan ve UNESCO Dünya Miras Listesi içerisinde yer almakta olan Safranbolu destinasyonunu ziyaret eden yerli turistler olarak kabul edilmiştir. Araştırmanın örneklemi ise 2016 döneminde destinasyonu ziyaret eden yerli turistler olarak belirlenmiştir. Safranbolu destinasyonunu 2015 yılında 190.111 yerli ve 53.996 yabancı olmak üzere toplam 244.107 turist ziyaret etmiş bulunmaktadır. Safranbolu destinasyonu için zaman, maliyet ve ulaşılabilirlik unsurları dikkate alınarak örneklem büyüklüğü güven aralığı $\%+-5, Z$ değeri ise 1,96 olmak üzere 384 olarak tespit edilmiştir.

Safranbolu destinasyonuna ziyaret gerçekleştiren yerli turistlerin tipolojileri ile seyahat öncesi bilgi araştırma davranışları arasındaki ilişkinin belirlenmesi bağlamında veri toplama aracı olarak anket kullanılmıştır. Araştırmada kullanılan anket kapsamında, turist tipolojilerine yönelik ölçek, Yalı (2016) çalışmasından yararlanılmıştır. Turistlerin seyahat öncesi bilgi araştırma davranışlarının belirlenmesinde ise Bonera (2008) ile Hamilton ve Lau (2004) tarafından gerçekleştirilen çalışmalar baz alınmakla birlikte ölçek soruları akademisyen görüşü kapsamında Safranbolu özeline indirgenmiştir.

Yerli turistlerin tipolojileri ile seyahat öncesi bilgi araştırması davranışlarını ortaya çıkarmaya yönelik olarak hazırlanan anketin birinci bölümünde; katılımcıların demografik (cinsiyet, medeni durum, yaş, eğitim durumu, aylık gelir, meslek) diğer (ziyaret partneri, bilgi kaynağı) özelliklerin belirlenmesinde sınıflama ölçeği kullanılmıştır. Anketin ikinci bölümü olan seyahat öncesi bilgi araştırma davranışı ve üçüncü bölümü olan turist tipolojisinde aralıklı ölçek kapsamında 5'li Likert Ölçeği kullanılmıştır. Likert ölçeği soruları; "1=Katılmıyorum; 2=Az Katılıyorum; 3=Kısmen Katılıyorum; 4=Katılıyorum; 5=Tamamen Katılıyorum" şeklinde kodlanmıştır. Anket ölçeği, Safranbolu'ya ziyaret gerçekleştiren 432 yerli turiste kolayda örneklem yöntemi kapsamında Mayıs-Eylül 2016 döneminde uygulanmıştır.

\section{Verilerin Analizi}

Araştırma kapsamında anket tekniği çerçevesinde toplanan veriler, bilgisayar ortamına aktarılıp veri tabanı oluşturulmuştur. Akabinde veriler, güvenirlik ve faktör analizine tabi tutulmuştur. $\mathrm{Bu}$ analizlerin sonuçları kapsamında turist tipolojisi ölçeği için 5 yargı, seyahat öncesi bilgi araştırma davranışı içinse 6 yargı, analiz değerlendirmesine alınmamıştır. Verilerin analizi kapsamında parametrik testlerin kullanılması için verilerin normallik dağılımına sahip bulunup, bulunmadığının belirlenmesi kapsamında çarpıklık ve basıklık katsayıları esas alınmıştır. Bu araştırmada turist tipolojileri için çarpıklık ve basıklık katsayıları; -0,377 ve 0,133, seyahat öncesi bilgi araştırma davranışı içinse $-0,158$ ve 0,013 olarak belirlenmiştir. Çarpıklık (Skewness) ve Basıklık (Kurtosis) değerlerinin (-+) 1 aralığında olması bağlamında araştırmada parametrik testleri kullanılabileceğine karar verilmiştir (Ayaz ve Aydın, 2018). Araştırma hipotezinin test edilmesi bağlamında ise "korelasyon" analizine başvurulmuştur. 


\section{BULGULAR}

Safranbolu ilçesini ziyaret eden yerli turistlerin demografik özellikleri (cinsiyet, yaş, eğitim durumu, aylık gelir, medeni durum ve meslek) ile diğer özelliklerinin (ziyaret partneri tercihi ve bilgi edinme kaynakları) yüzde ve frekans analizi kapsamında incelenmiş ve Tablo 1'de sunulan bilgilere ulaşılmıştır.

Tablo 1. Katılımcılara İlişkin Tanımlayıcı Bilgiler ( $\mathrm{n}=457)$

\begin{tabular}{|c|c|c|c|c|c|c|c|}
\hline Değiş̧ken & Gruplar & f & $\%$ & Değişken & Gruplar & f & $\%$ \\
\hline \multirow{2}{*}{ Cinsiyet } & Kadın & 302 & 69,9 & \multirow{2}{*}{$\begin{array}{l}\text { Medeni } \\
\text { Durum }\end{array}$} & Evli & 133 & 30,8 \\
\hline & Erkek & 130 & 30,1 & & Bekâr & 299 & 69,2 \\
\hline \multirow{6}{*}{ Yaş } & 18 ve alt 1 & 67 & 15,5 & \multirow{5}{*}{ Meslek } & İş adamı & 28 & 6,5 \\
\hline & $19-25$ yaş & 171 & 39,6 & & Memur & 50 & 11,6 \\
\hline & $26-32$ yaş & 95 & 22,0 & & İşçi & 73 & 16,9 \\
\hline & $33-39$ yaş & 49 & 11,3 & & Emekli & 20 & 4,6 \\
\hline & $40-46$ yaş & 29 & 6,7 & & Diğer & 261 & 60,4 \\
\hline & 47 ve üzeri & 21 & 4,9 & \multirow{4}{*}{$\begin{array}{l}\text { Ziyaret } \\
\text { Partneri }\end{array}$} & Yalnız kendim & 45 & 10,4 \\
\hline \multirow{5}{*}{ Eğitim } & İlköğretim & 11 & 2,5 & & Ailem & 205 & 47,5 \\
\hline & Ortaöğretim & 80 & 18,5 & & Akraba & 36 & 8,3 \\
\hline & Ön lisans & 137 & 31,7 & & Arkadaş & 146 & 33,8 \\
\hline & Lisans & 164 & 38,0 & \multirow{8}{*}{$\begin{array}{c}\text { Ziyaret } \\
\text { Bilgi } \\
\text { Kaynağı }\end{array}$} & Turistik kataloglar & 26 & 6,0 \\
\hline & Lisansüstü & 40 & 9,3 & & Broşürler & 6 & 1,4 \\
\hline \multirow{6}{*}{$\begin{array}{l}\text { Aylık } \\
\text { Gelir }\end{array}$} & 750 TL ve alt 1 & 129 & 29,9 & & Arkadaşlar & 86 & 19,9 \\
\hline & $751-1250 \mathrm{TL}$ & 75 & 17,4 & & Akrabalar & 69 & 16,0 \\
\hline & $1251-2000 \mathrm{TL}$ & 76 & 17,6 & & Turizm Dergileri & 6 & 1,4 \\
\hline & $2001-2750 \mathrm{TL}$ & 60 & 13,9 & & Internet & 198 & 45,8 \\
\hline & $2751-3250 \mathrm{TL}$ & 49 & 11,3 & & Seyahat Acentas1 & 32 & 7,4 \\
\hline & 3251 TL ve üzeri & 43 & 10,0 & & Diğger & 9 & 2,1 \\
\hline
\end{tabular}

Safranbolu'yu ziyaret eden yerli turistlerin tipolojilerine yönelik verilerin faktör analizine uygunluğu kapsamında KMO (Kaiser-Meyer-Olkin) Örneklem Ölçüm Değer Yeterliliği değeri 0.77 ve Bartlett Küresellik Testi anlamlılık düzeyi; $p=0,000$ olarak belirlenmiştir. Bu sonuçlar kapsamında gerçekleştirilen faktör analizinde 11 yargıya ait 3 alt boyut (araştırmacı turist, organize kitle turist, maceracı turist) için toplam güvenilirlik katsayısı 0,77 ve varyans açılama oranı 57,90 olarak tespit edilmiştir (Tablo 2).

Safranbolu'ya ziyaret gerçekleştiren yerli turistlerin bilgi araştırma davranışlarının ortaya konulması bağlamında elde edilen verilere çalışmanın araştırma soruları ve hipotezinin test edebilmesi için açıklayıcı faktör analizi yapılması öngörülmüştür. Bununla birlikte ilk önce faktör analizi için verilerin uygunluk derecesini tespit etmek amaciyla KMO Örneklem Ölçüm Yeterliliği ve Bartlett's küresellik anlamlılık testleri yapılmıştır. KMO Örneklem Ölçüm Değer 
Yeterliliği 0.75 , Bartlett Küresellik Testi anlamlılık düzeyi; $\mathrm{p}=0,000$ olarak belirlenmiştir. Safranbolu'yu ziyaret eden yerli turistlerin satın alma öncesi bilgi araştırma sürecindeki davranışlarının faktör analizinde 15 yargıya ait 5 alt boyut için güvenilirlik katsayısı 0,80 ve varyans açıklama oranı 65,62 olarak tespit edilmiştir.

Tablo 2. Safranbolu'yu Ziyaret Eden Turist Tipolojilerine İlişkin Faktör Analizi

\begin{tabular}{|c|c|c|c|c|c|}
\hline Faktör & $\bar{x}$ & ss & $\begin{array}{l}\text { Faktör } \\
\text { Yükü }\end{array}$ & $\alpha$ & $\begin{array}{l}\text { Varyans } \\
\text { Açılama } \\
(\%) \\
\end{array}$ \\
\hline Araştırmacı Turist & 3,82 & 0,79 & & & \multirow{7}{*}{27,614} \\
\hline Ziyaret ettiğim yerde yerli halk ile tanışmayı severim. & 3,81 & 1,11 & 0,769 & & \\
\hline Ziyaret ettiğim yerin kültürünü öğrenmek isterim. & 4,08 & 0,96 & 0,768 & & \\
\hline $\begin{array}{lll}\begin{array}{l}\text { Ziyaret ettiğim yerdeki } \\
\text { deneyimlemek isterim. }\end{array} & \text { geleneksel yaşamı } \\
\end{array}$ & 3,71 & 1,17 & 0,765 & & \\
\hline $\begin{array}{l}\text { Ziyaret ettiğim yerde yöresel yemekleri tatmak } \\
\text { isterim. }\end{array}$ & 4,21 & 0,96 & 0,705 & & \\
\hline $\begin{array}{l}\text { Ziyaret ettiğim yerde yerli halkın evlerinde misafir } \\
\text { olmaktan onur duyarım. }\end{array}$ & 3,12 & 1,40 & 0,617 & & \\
\hline $\begin{array}{l}\text { Ziyaret ettiğim yerde önceden keşfedilmemiş yeni } \\
\text { yerleri gezmeyi severim. }\end{array}$ & 4,00 & 1,01 & 0,560 & & \\
\hline Organize Kitle Turist & 2,96 & 1,05 & & & \multirow{5}{*}{18,416} \\
\hline $\begin{array}{l}\text { Ziyaret ettiğim yerde bir gruba dahil olarak gezmeyi } \\
\text { tercih ederim. }\end{array}$ & 2,96 & 1,30 & 0,862 & & \\
\hline $\begin{array}{l}\text { Ziyaret ettiğim yerde önceden planlanmış gezi } \\
\text { programlarına dahil olmayı tercih ederim. }\end{array}$ & 3,23 & 1,25 & 0,835 & & \\
\hline $\begin{array}{l}\text { Ziyaret ettiğim yerde kısa süreli konaklamasız } \\
\text { gezileri tercih ederim. }\end{array}$ & 2,67 & 1,34 & 0,696 & & \\
\hline Maceracı Turist & 3,05 & 0,95 & & & \\
\hline $\begin{array}{l}\text { Ziyaret ettiğim yerde kalabalıktan uzak yerleri tercih } \\
\text { ederim. }\end{array}$ & 3,12 & 1,28 & 0,801 & & \multirow[b]{2}{*}{11,875} \\
\hline $\begin{array}{l}\text { Ziyaret ettiğim yerde yemek yiyeceğim restoranları } \\
\text { önceden keşfedilmemiş yerlerden seçerim. }\end{array}$ & 2,97 & 1,21 & 0,655 & & \\
\hline \multicolumn{4}{|l|}{ Toplam Cronbach Alpha/Varyans Açıklama (\%) } & 0,77 & 57,905 \\
\hline
\end{tabular}

KMO Örneklem Ölçüm Yeterliği: 0,778

Barlett's Anlamlllık Testi (Chi-Square / df / Sig): 1226,686/ 55 / 0,000

Araştırma kapsamında Safranbolu destinasyonunu ziyaret gerçekleştiren turistlerin tipolojileri ile bilgi araştırma davranışları arasında anlamlı bir ilişkinin bulunup bulunmadığının ortaya çıarılması ve araştırmada öngörülen " $\mathrm{H}_{1}$ : Yerli turistlerin tipolojileri ile seyahat öncesi bilgi araştırma davranışları arasında anlamlı bir ilişki vardır." hipotezin test edilmesi kapsamında Korelasyon Analizi öngörülmüştür. 
Türk Turizm Araştırmaları Dergisi, 4(2): 1060-1076.

Tablo 3. Turistlerin Bilgi Edinme Davranışına İlişkin Faktör Analizi

\begin{tabular}{|c|c|c|c|c|c|}
\hline Faktör & $\bar{x}$ & ss & $\begin{array}{l}\text { Faktör } \\
\text { Yükü }\end{array}$ & $\alpha$ & $\begin{array}{c}\text { Varyans } \\
\text { Açılklama } \\
(\%) \\
\end{array}$ \\
\hline Destinasyon Genel Özellikleri & 2,90 & 0,92 & & & \multirow{6}{*}{18,116} \\
\hline $\begin{array}{l}\text { Tatil kararım öncesinde Safranbolu'yu } \\
\text { ziyaret eden turist sayısı hakkında bilgi } \\
\text { edindim. }\end{array}$ & 2,94 & 1,31 & 0,741 & & \\
\hline $\begin{array}{l}\text { Tatil kararım öncesinde Safranbolu'dan } \\
\text { satın alınabilecek hediyelik eşyalar } \\
\text { hakkında bilgi edindim. }\end{array}$ & 3,16 & 1,32 & 0,713 & & \\
\hline $\begin{array}{l}\text { Tatil kararım öncesinde Safranbolu'daki } \\
\text { spor imkanları hakkında bilgi edindim. }\end{array}$ & 2,70 & 1,31 & 0,704 & & \\
\hline $\begin{array}{l}\text { Tatil kararım öncesinde Safranbolu'daki } \\
\text { nüfus hakkında bilgi edindim. }\end{array}$ & 2,68 & 1,21 & 0,684 & & \\
\hline $\begin{array}{l}\text { Tatil kararım öncesinde Safranbolu'daki } \\
\text { yerel halkın misafirperverliği hakkında bilgi } \\
\text { edindim. }\end{array}$ & 3,04 & 1,23 & 0,673 & & \\
\hline Ulaşım-Konaklama İmkanları & 4,12 & 0,75 & & & \multirow{5}{*}{15,463} \\
\hline $\begin{array}{l}\text { Tatil kararım öncesinde Safranbolu'ya } \\
\text { ulaşım olanakları hakkında bilgi edindim. }\end{array}$ & 4,09 & 1,01 & 0,760 & & \\
\hline $\begin{array}{l}\text { Tatil kararım öncesinde Safranbolu'daki } \\
\text { konaklama işletmeleri hakkında bilgi } \\
\text { edindim. }\end{array}$ & 4,21 & 0,98 & 0,751 & & \\
\hline $\begin{array}{l}\text { Tatil kararım öncesinde Safranbolu'ya } \\
\text { seyahat mesafem hakkında bilgi edindim. }\end{array}$ & 4,12 & 1,00 & 0,739 & & \\
\hline $\begin{array}{l}\text { Tatil kararım öncesinde Safranbolu'daki } \\
\text { fiyatlar (ulaşım, konaklama) hakkında bilgi } \\
\text { edindim. }\end{array}$ & 4,07 & 1,01 & 0,657 & & \\
\hline Seyahat Güzergahları & 3,95 & 0,93 & & & \\
\hline $\begin{array}{l}\text { Tatil kararım öncesinde Safranbolu'daki } \\
\text { doğal güzellikler hakkında bilgi edindim. }\end{array}$ & 3,95 & 0,96 & 0,929 & & \\
\hline $\begin{array}{l}\text { Tatil kararım öncesinde Safranbolu'daki } \\
\text { tarihi ve kültürel yerler hakkında bilgi } \\
\text { edindim. }\end{array}$ & 3,95 & 1,00 & 0,925 & & 12,207 \\
\hline Sağlık-Güvenlik İmkanları & 3,48 & 1,08 & & & \\
\hline $\begin{array}{l}\text { Tatil kararım öncesinde Safranbolu'daki } \\
\text { sağlık hizmetleri hakkında bilgi edindim. }\end{array}$ & 3,29 & 1,24 & 0,830 & & 11,253 \\
\hline $\begin{array}{l}\text { Tatil kararım öncesinde Safranbolu'daki } \\
\text { güvenlik durumu hakkında bilgi edindim. }\end{array}$ & 3,69 & 1,17 & 0,809 & & \\
\hline Eğlence İmkanları & 3,20 & 1,05 & & & \\
\hline $\begin{array}{l}\text { Tatil kararım öncesinde Safranbolu'daki } \\
\text { alkol tüketilebilecek mekanlar hakkında } \\
\text { bilgi edindim. }\end{array}$ & 2,64 & 1,48 & 0,799 & & 8,591 \\
\hline $\begin{array}{l}\text { Tatil kararım öncesinde Safranbolu'daki } \\
\text { eğlence yerleri hakkında bilgi edindim. }\end{array}$ & 3,77 & 1,14 & 0,759 & & \\
\hline $\begin{array}{l}\text { Toplam Cronbach Alpha/Varyans Açılama } \\
\text { (\%) }\end{array}$ & & & & $\mathbf{0 , 8 0}$ & 65,629 \\
\hline
\end{tabular}

KMO Örneklem Ölçüm Değer Yeterliliği: 0,751, Bartlett's Kürsellik Testi (Chi-Square / df / Sig): 1963,046/ 105 / 0,000 
Korelasyon analizi; iki farklı değişken arasındaki ilişki veya bağımlılık durumunu açıklamak için tercih edilen bir analiz olup, analizde korelasyon katsayısı " $\mathrm{r}$ " değerinin $+/-1$ arasında bir değer alması beklenmektedir. Analiz sonucunda " $r$ " değerinin eksi olması, negatif yönlü bir ilişki; artı olması ise pozitif ilişkinin varlığına işarettir. Bununla birlikte, " $r$ " değerinin 0,00-0,29 arasında olması halinde "düşük", 0,30-0,69 arasında olması halinde "orta", 0,70 ve üzeri çıkması halinde ise "yüksek" düzeyde ilişkinin varlığı şeklinde değerlendirilmesinin gerektiği belirtilmektedir (Ural ve Kılıç, 2006).

$\mathrm{Bu}$ araştırmada turist tipolojileri için çarpıklık ve basıklık katsayıları; $-0,377$ ve 0,133, seyahat öncesi bilgi araştırma davranışı içinse $-0,158$ ve 0,013 olarak belirlenmiştir. Çarpıklık (Skewness) ve Basıklık (Kurtosis) değerlerinin (- +) 1 aralığında olması bağlamında araştırmada parametrik testleri kullanılabileceğine karar verilmiştir. Bu kapsamda Korelasyon analizi için Pearson Korelasyon Analizi esas alınmış ve Tablo 4'te sunulmakta olan analiz sonuçlarına ulaşılmıştır:

Tablo 4. Turist Tipolojileri ve Bilgi Araştırma Davranışına İlişkin Korelasyon Analizi

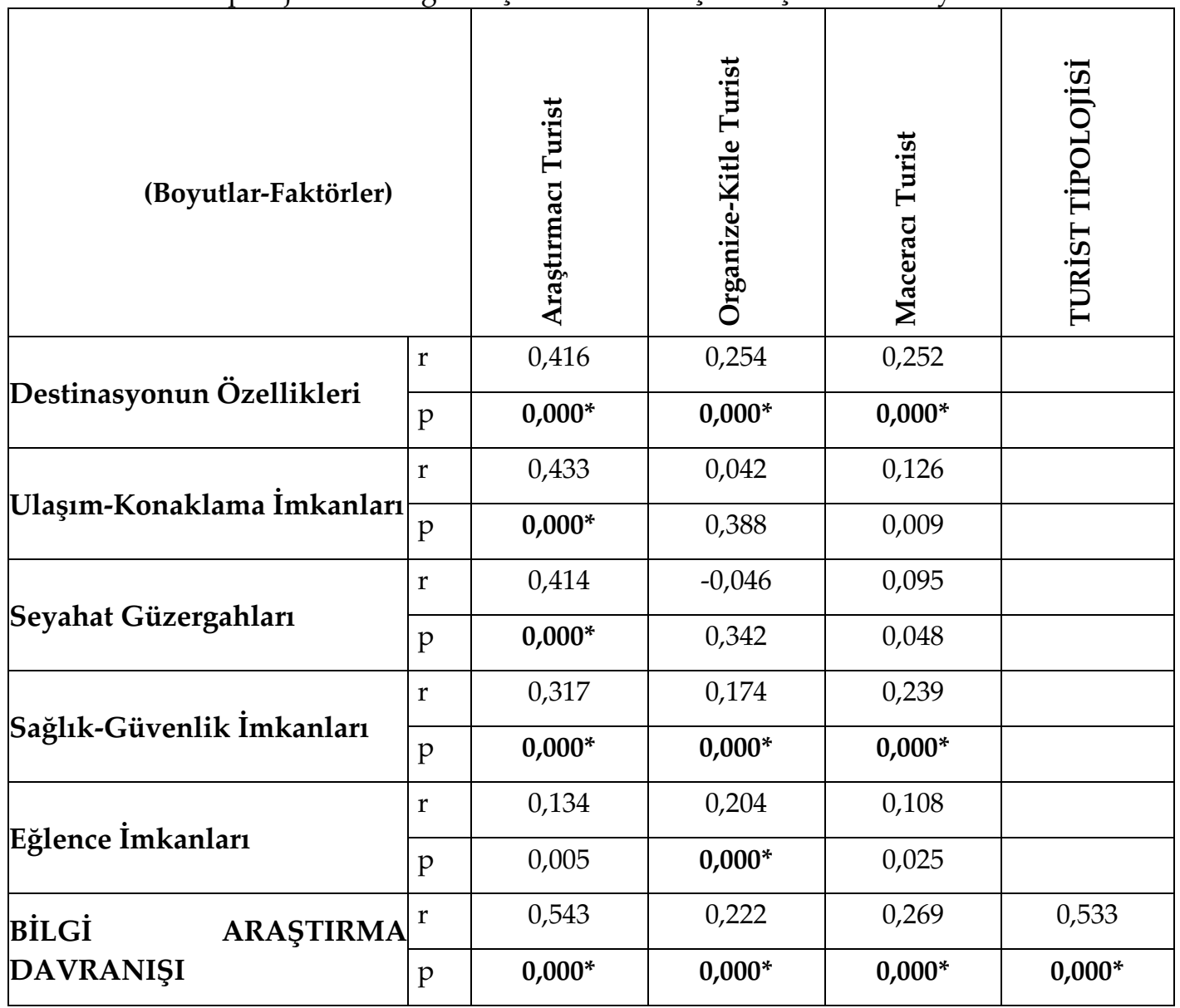

$*(\mathrm{p}<0,001)$

Tablo 4'te gerçekleştirilen Pearson Korelasyon Analizi göre Safranbolu'yu ziyaret eden yerli turist tipolojileri (araştırmacı, organize kitle, maceracı) ile bilgi araştırma davranışları (destinasyon özellikleri, ulaşım-konaklama imkanları, seyahat güzergahları, sağlık-güvenlik imkanları, eğlence imkanları) ilişkin bulgular arasında 0,001 anlamlılık düzeyinde bir ilişki aranmıştır. Buna göre; 
-Safranbolu'yu ziyaret gerçekleştiren araştırmacı turist tipolojisi ile destinasyon özelliklerine yönelik bilgi arama davranışı arasındaki " $r$ " değerinin 0,416 olması, orta düzeyde $(0,30<r<0,69)$ pozitif yönde doğrusal bir ilişki olduğu göstermektedir. Bu sonuç kapsamında araştırmacı turistlerin bir destinasyona ilişkin özellikleri araştırmada ilgi düzeylerinin organize kitle $(r=0,254)$ ve maceracı $(\mathrm{r}=0,252)$ turistlere göre daha fazla olduğu söylenebilir.

-Safranbolu'yu ziyaret eden araştırmacı turist tipolojisi ile ulaşım-konaklama imkanlarına yönelik bilgi araştırması davranışı arasında " $r$ " değeri 0,433 olmak üzere orta düzeyde $(0,30<\mathrm{r}<0,69)$ pozitif yönde doğrusal bir ilişki olduğu görülmektedir. Bu sonuç çerçevesinde araştırmacı turistlerin ulaşım-konaklama imkanları hakkında organize kitle turistleri $(p=0,388)$ ve maceracı $(\mathrm{r}=0,009)$ turistlere göre bilgi edinen tek turist tipolojisi olduğunu söylemek mümkündür.

-Safranbolu'yu ziyaret eden araştırmacı turist tipolojisi ile seyahat güzergahlarına yönelik bilgi araştırması davranışı arasında " $r$ " değeri; 0,414 olmak üzere orta düzeyde $(0,30<r<0,69)$ pozitif yönde doğrusal bir ilişki olduğu görülmektedir. Bu sonuç çerçevesinde araştırmacı turistlerin ulaşım-konaklama imkanları benzer şekilde seyahat güzergahlarında da organize kitle turistleri $(\mathrm{p}=0,342)$ ve maceracı $(\mathrm{p}=0,048)$ turistlere göre bilgi edinen tek turist tipolojisi olduğunu söylemek mümkündür.

-Safranbolu'yu ziyaret eden araştırmacı turist tipolojisi ile sağlık-güvenlik imkanları bilgi araştırması davranışı arasında " $r$ " değeri; 0,317 olmak üzere orta düzeyde $(0,30<r<0,69)$ pozitif yönde doğrusal bir ilişki olduğu görülmektedir. Bu sonuç kapsamında araştırmacı turistlerin bir destinasyona ilişkin özellikleri araştırmada ilgi düzeylerinin organize kitle $(r=0,174)$ ve maceracı $(\mathrm{r}=0,239)$ turistlere göre daha fazla olduğu söylenebilir.

-Safranbolu'yu ziyaret eden araştırmacı turist tipolojisi ile eğlence imkanlarına yönelik bilgi araştırması davranışı arasındaki " $\mathrm{p}$ " değerinin; 0,005 olması bağlamında bir ilişkinin bulunmadığını şeklinde yorumlanabilir.

-Safranbolu'yu ziyaret eden organize kitle turist tipolojisi ile destinasyon özelliklerine yönelik bilgi araştırması davranışı arasındaki " $r$ " değeri; 0,254 olmak üzere düşük düzeyde $(0,00<r<0,29)$ pozitif yönde doğrusal bir ilişki olduğu görülmektedir. Bu durumda, organize kitle turistlerinin seyahat öncesinde destinasyon özellikleri hakkında bilgi edinmeye önem verdikleri söylenebilir.

-Safranbolu'yu ziyaret eden organize kitle turist tipolojisi ile ulaşım-konaklama imkanlarına yönelik bilgi araştırması davranışı arasında " $p$ " değerinin 0,388 olması bağlamında bir ilişkinin bulunmadığı şeklinde ifade edilebilir. Bu sonuç kapsamında, organize kitle turistlerin çoğunlukla tur seyahat ettikleri için ulaşım-konaklama imkanlarında bilgi araştırmasına gerek duymadığ şeklinde yorumlanabilir.

-Safranbolu'yu ziyaret eden organize kitle turist tipolojisi ile sağlık-güvenlik imkanlarına yönelik bilgi araştırması davranışı arasındaki " $r$ " değerinin 0,174 olması düşük düzeyde $(0,00<r<0,29)$ pozitif yönde doğrusal bir ilişki olduğunu göstermektedir. Bu durum, organize kitle turistlerinin seyahat öncesi sağlık-güvenlik imkanları hakkında bilgi araştırması yaptıkları şeklinde yorumlanabilir.

-Safranbolu'yu ziyaret eden organize kitle turist tipolojisi ile eğlence imkanlarına yönelik bilgi araştırması davranışı arasındaki " $r$ " değerinin 0,204 olması, düşük düzeyde $(0,00<r<0,29)$ pozitif yönde doğrusal bir ilişki olduğu göstermektedir. Bu durumda, organize kitle turistlerin seyahat kararı öncesinde eğlence imkanları hakkında bilgi edinmeye yöneldikleri düşünülebilir.

-Safranbolu'yu ziyaret eden maceracı turist tipolojisi ile destinasyon özelliklerine yönelik bilgi araştırması davranışı arasında " $r$ " değeri; 0,252 olmak üzere düşük düzeyde $(0,00<r<0,29)$ pozitif 
yönde doğrusal bir ilişki olduğu görülmektedir. Bu sonuç kapsamında maceracı turistlerin seyahate çıkmadan önce destinasyon özellikleri hakkında bilgi araştırmasına yöneldikleri söylenebilir.

-Safranbolu'yu ziyaret eden maceracı turist tipolojisi ile ulaşım-konaklama imkanlarına yönelik bilgi araştırması arasında " $p$ " değerinin 0,009 olması bağlamında doğrusal bir ilişkinin bulunmadığı görülmektedir. Bu durumda, maceracı turistlerin ulaşım-konaklama imkanlarını önemsemediğini söylemek mümkündür.

-Safranbolu'yu ziyaret eden maceracı turist tipolojisi ile seyahat güzergahları arasındaki " $p$ " değerinin 0,048 olması bağlamında doğrusal bir ilişkinin bulunmadığı görülmektedir. Bu durum, ulaşım ve konaklama imkanlarında olduğu gibi maceracı turistlerin seyahat güzergahlarını önemsemedikleri şeklinde yorumlanabilir.

-Safranbolu'yu ziyaret eden maceracı turist tipolojisi ile sağlık-güvenlik imkanlarına yönelik bilgi araştırması davranışı arasında " $r$ " değeri; 0,239 olmak üzere düşük düzeyde $(0,00<r<0,29)$ pozitif yönde doğrusal bir ilişki olduğu görülmektedir. Bu durumda, maceracı turistlerin, her ne kadar maceracı bir kimlik taşısalar da seyahat sağlık-güvenlik imkanları hakkında bilgi edindikleri şeklinde açıklanabilir.

-Safranbolu'yu ziyaret eden maceracı turist tipolojisi ile eğlence imkanlarına yönelik bilgi araştırması davranışı arasındaki " $\mathrm{p}$ " değerinin 0,025 olması kapsamında pozitif yönde doğrusal bir ilişkinin bulunmadığı görülmektedir. Bu sonuç kapsamında, maceracı yerli turistlerin maceracı kimliklerine rağmen eğlence imkanları hakkında bilgi edinmediği söylenebilir.

-Safranbolu'ya ziyaret gerçekleştiren turistlerin tipolojisi ile bilgi araştırması arasındaki " $r$ " değeri; 0,543 olmak üzere orta düzeyde $(0,30<r<0,69)$ pozitif yönde doğrusal bir ilişki olduğu görülmektedir. Bu ilişki kapsamında araştırma için önerilen "H1: Yerli turistlerin tipolojileri ile seyahat öncesi bilgi araştırma davranışları arasında anlamlı bir ilişki vardır" hipotezi bu araştırma için kabul edilmiştir. Bu sonuç kapsamında seyahat öncesi bilgi araştırmasına yönelik olarak yapılacak çalışmalarda pazarlamacıların turistlerin tipolojilerine göre pazarlama faaliyetlerinde yönelmesi yerinde olacaktır.

Bu sonuç kapsamında seyahat öncesi bilgi araştırmasına yönelik olarak yapılacak çalışmalarda pazarlamacıların turistlerin tipolojilerine göre pazarlama faaliyetlerine yönelmesi yerinde olacaktır. Çünkü, destinasyon seçimi ile ilgili karar vermede bilgi de dahil olmak üzere birçok faktörden etkilenir. Destinasyon konusunda daha bilgili olanların, daha az ilgili olanlardan daha fazla bilgi aramaya daha yatkın olduğu belirtilmektedir (Andereck, 2009).

\section{TARTIŞMA, SONUÇ VE ÖNERILLER}

Turistik faaliyetlerden gelir elde etme her geçen gün daha fazla önemli hale gelmekte ve ülkelerin ekonomisindeki payını artırmaktadır. Bu anlamda turistleri bir destinasyona ziyaret için çeken şeylerin önceden öğrenilmesi önemli bir gereklilik olarak görülebilir. Özellikle seyahat öncesi turistlerin davranışlarının öğrenilmesi, geleceğe yönelik pazarlama planlamalarının şekillendirilmesi açısından oldukça önemli bir gereklilik olarak değerlendirilebilir. Çoğu turist için bilgi arama; maliyetlere yönelik avantajlarının ortaya çıkarılması, tasarruf, seçim kalitesini yükseltebilme ve riskleri azaltabilme olarak görülebilir.

Turistlerin günlük hayatta bilgiyi nasıl elde ettiği ve satın alma kararlarını nasıl şekillendirdiği konusunda farklı görüşler; yakın çevrelerinde yer alan kimselerin yaşadıkları geçmiş deneyimler, kendileri için uygun kabul ettikleri rol ve modellerin davranışları, sosyal gruplar ve bilgiye olan erişimi kolaylaştıran internetin sıkça kullanımı yönündedir. Bilgi araştırmasında öne çıkan 
temalar ise destinasyonda yer alan gezilecek yerler, konaklama işletmeleri, hijyen durumu, güvenlik imkanları, fiyatlar ve yerel halkın turiste olan tutumu şeklinde ortaya çıkabilmektedir (Ayaz vd., 2015; Ayaz ve Yalı, 2017).

$\mathrm{Bu}$ araştırmada Safranbolu'ya ziyaret gerçekleştiren yerli turistlerin tipolojileri ve bilgi araştırma davranışlarının ortaya çıkarılması amaçlanmıştır. Çalışmanın Safranbolu destinasyon paydaşlarına ve karar vericilere yol gösterici olması beklenmektedir. Ayrıca turistlerin bilgi araştırma davranışına bir bakış açısı oluşturma, Safranbolu'ya yönelik memnuniyet düzeyini artırma ve beklentileri karşılamada da yardımcı olabileceği düşünülmektedir. Bu çerçevede Mayıs-Eylül 2016 döneminde Safranbolu'ya ziyaret gerçekleştiren eden 432 yerli ziyaretçiden toplanan veriler ile turistlerin tipolojileri ile bilgi araştırma davranışı arasındaki ilişki test edilmiş ve aşağıdaki sonuçlara ulaşılmıştır:

-Safranbolu'yu ziyaret eden turist tipolojilerinde araştırmacı turist, maceracı turist ve organize kitle turist önceliğinde olmak üzere üç alt boyut saptanmıştır. Bu sonuçlar bazında Safranbolu destinasyonunu daha çok araştırmacı turistlerin tercih ettiğini söylemek mümkündür.

-Safranbolu'yu ziyaret gerçekleştiren yerli turistlerin bilgi arama davranışı ulaşım-konaklama imkanları, seyahat güzergahları, sağlık-güvenlik imkanları, eğlence imkanları ve destinasyon özellikleri önceliğinde olmak üzere beş alt boyut belirlenmiştir. Bu sonuçlar kapsamında yerli turistlerin seyahat öncesi bilgi arama davranışlarında en çok önemi ulaşım-konaklama imkanlarına ve seyahat güzergahlarına önem verdikleri şeklinde yorumlanabilir.

-Araştırma kapsamında Safranbolu destinasyonunu ziyaret gerçekleştiren turistlerin tipolojileri ile bilgi araştırma davranışları arasında orta düzeyde pozitif yönlü doğrusal bir orta düzeyde bir ilişkinin olduğu görülmüştür.

$\mathrm{Bu}$ ölçüm sonuçları kapsamında destinasyon pazarlamacıları, yöneticileri ve turizm işletme yetkililerinin insanların seyahat öncesi bilgi araştırmasına yönelik çalışmalarda turistlerin tipolojilerine göre pazarlama faaliyetlerinde yönelmesi ve seyahat planlaması çalışmalarında bilgileri değerlendirme, edinme ve kullanma konusunda turistlerin stratejik ihtiyaçlarını dikkate almaları gerekmektedir. Bu süreçte Safranbolu destinasyonu özelinde turist tipolojisi ve bilgi arama davranışı konusunda seminer ve eğitim çalışmaları ile bilgilendirilme ve desteklenmeleri önem arz etmektedir.

$\mathrm{Bu}$ araştırma ile Safranbolu destinasyona ziyaret gerçekleştiren turistlerin tipolojisi ile bilgi arama davranışı arasındaki ilişkiye yönelik bir kavramsal bir yapı oluşturulmuştur. Turizm sektöründe hizmet sunmakta olan işletme yöneticilerine ve karar vericilere yol gösterici olması beklenen bu çalışmaya benzer gelecekteki araştırmalarda farklı destinasyonlar için bu araştırmada geliştirilen ölçekler baz alınarak yapılacak çalışmalarla farklı öngörüler geliştirilebilir. Ayrıca bu araştırmada turistlerin bilgi arama davranışı araştırmacı turist, maceracı turist ve organize kitle turist tipolojisi ile ilişkilendirilmiştir. Gelecekteki benzer çalışmalarda farklı turist tipolojileri ile bilgi edinme davranışı ilişkilendirilebilir ve farklı öngörüler geliştirilebilir.

\section{KAYNAKÇA}

Akay, B., Uslu, A. ve Sancar, M. F. (2014). Turizm örgütlerinin turizme etkilerinin belirlenmesine yönelik bir araştırma. Journal of Recreation and Tourism Research, 1(4), 6-14.

Akkılıç, M. E. (2002). Turizm pazarlaması ile oluşan faydaların tespiti ve bu faydaların turizm aracı kuruluşlarının reklam faaliyetlerine yansıtılmasının önemi. Yayımlanmamış Doktora Tezi. İnönü Üniversitesi Sosyal Bilimler Enstitüsü, Malatya. 
Andereck, K. L. (2009). Tourism product involvement and information search. https://scholarworks.umass.edu/ttra/2009/Illustrated_Papers/1 [Erişim Tarihi: 05.03.2019].

Ayaz, N. ve Aydın, A. (2018). Yiyecek ve içecek işletmelerinde iş motivasyonun hijyen davranışına etkisi: İşgörenler üzerine bir araştırma. Seyahat ve Otel İşletmeciliği Dergisi, 15(2), 287301.

Ayaz, N. ve Yall, S. (2017). Kültürel Turistlerin Seyahat Tercihleri ve Yiyecek-İçecek Beklentileri: Safranbolu Örneği, Türk Turizm Araştırmaları Dergisi, 1(1), 43-61.

Ayaz, N., Batı, T. ve Gökmen F. (2015). Safranbolu'yu Ziyaret Eden Yabancı Turistlerin Destinasyon İmajı Algıları. Karabük Üniversitesi Sosyal Bilimler Enstitüsü Dergisi, Özel Sayı-1, 5469.

Baysal, C. ve Tekarslan, E. (2004). İşletmeler İçin Davranış Bilimleri. Avcıol Basım Yayın. İstanbul.

Bonera, M. (2008). The vacation decision making process: Tourism in The Garda Lake. 8th Global Conference on Business \& Economics. Florence, Italy.

Case, D.O. (2007). Looking for information. A survey of research on information seeking, needs and behavior. San Diego, CA: Academic Press.

Coccosss, H. and Constantoglou, M. E. (2006). The use of typologies in tourism planning: Problems and Conflicts. 46th Congress of the European Regional Science Association (ERSA) Enlargement, Southern Europe and the Mediterranean.

Demir, Ş. Ş. ve Kozak, M. (2011). Turizmde tüketici davranışları modelini oluşturan aşamalar arasındaki ilişki. Anatolia: Turizm Araştırmaları Dergisi, 22 (1), 19-34.

Dervin, B. and M. Nilan. (1986). Information needs and uses. Annual Review of Information Science and Technology, 21, 3-33.

Dey, B. and Sarma, M. K. (2006) Tourist typologies and segmentation variables with regard to ecotourists. Tourism Management ,8, 31-39.

Hamilton, J. M. and Lau, M. A. (2004). The role of clime information in tourist destination choice decision-making. Working Paper FNU-56. Center for Marine and Climate Research. Hamburg, Germany: Hamburg University.

Hvenegaard, G. T. (2002). Using tourist typologies for ecotourism research. Journal of Ecotourism, 1(1), 7-18.

Hawkins, D. I., Mothersbaugh, D. L. and Best, R.J. (2013). Consumer Behavior: Building Marketing Strategy. McGraw-Hill Irwin.

Hayta, A. B. (2008). Turizm pazarlamasında tüketici satın alma süreci ve karşılaşılan sorunlar. Kastamonu Ĕ̆itim Dergisi, 16(1), 31-48.

https://courses.lumenlearning.com/marketing-spring2016/chapter/reading-buying-processstages/> [Erişim Tarihi: 01.02.2019].

https://www.mbaknol.com/industrial-marketing/industrial-buying-behavior-models/> [Erişim Tarihi: 01.02.2019].

Hui Lin, C., Wan Chuang, Y. and Ying Chang, C. (2016). Study of the travel information resources, destination image, and behavioral intention of college students on Green Island. International Journal of Information Technology and Business Management, 54(1), 16-27. 
Türk Turizm Araştırmaları Dergisi, 4(2): 1060-1076.

Karasar, N. (1995). Bilimsel Araştırma Yöntemi, Kavramlar, İlkeler. 3A Araştırma Eğitim Danışmanlık Ltd. Ankara.

Kılıçbey, M. (2017). Genel Turizm. Gazi Kitabevi. Ankara.

Kotler, P. (2000). Marketing Management. Prentice Hall International, Inc., The Millennium Edition, New Jersey.

Kuester, S. (2012). MKT 301: Strategic Marketing and Marketing in Specific Industry Contexts. The University of Mannheim.

Kuhlthau, C.C. (1993). A principle of uncertainly for information seeking. Journal of Documentation, 49(4), 339-355.

Lowry, L. L. (2017). The Sage International Encyclopedia of Travel and Tourism. Sage Publications. Thousand Oaks.

Marchionini, G. (1989). Information-seeking strategies of movies using a full-text electronic encylopedia. Journal of the American Society for Information Science, 40(1), 54-66.

Marwijk, R. and Taczanowska, K. (2006). Types of typologies: From recreationists \& tourists to artificial agents. Proceedings of the Third International Conference on Monitoring and Management of Visitor Flows in Recreational and Protected Areas (p.499-501). University of Applied Sciences Rapperswil, Switzerland, 13-17 September.

Middleton, V. T. C. and Hawkins, R. (1998). Sustainable Tourism: A Marketing Perspective. (First published), London: Butterworth-Heinemann.

Orel, F. D. ve Memmedov, İ. (2003). Turizmde Hizmet Pazarlaması Türkiye Açısından Rusya Pazarı. Adana: Karahan Kitabevi.

Paksoy, S. (1994). Turizm pazarlaması ve Kapadokya bölgesindeki (Nevşehir yöresi) otel işletmelerinde pazarlama faaliyetleri. Yayımlanmamış Yüksek Lisans Tezi. Erciyes Üniversitesi Sosyal Bilimler Enstitüsü, Kayseri.

Pekyaman, A. (2008). Turistik satın alma davranışında destinasyon imajının rolü Afyonkarahisar bölgesinde bir araştırma. Yayımlanmamış Doktora Tezi, Afyon Kocatepe Üniversitesi Sosyal Bilimler Enstitüsü, Afyonkarahisar.

PSHE (2009). Introduction to Tourism. Hong Kong: Tourism and Hospitality Studies.

Rızaoğlu, B. (2007). Turizm Pazarlaması. Ankara: Detay Yayıncılık.

Rouse, W. B. and Rouse, S. H. (1984). Human information seeking and design of information systems. Information Processing and Management, 20(1,2), 129-138.

Soylu, D. (2016). Günlük bilgi gereksinimi ve bilgi arama davranışları üzerine bir çalışma: Ankara Adnan Ötüken İl Halk Kütüphanesi örneği. Yayımlanmamış Yüksek Lisans Tezi, Hacettepe Üniversitesi, Hacettepe Üniversitesi Sosyal Bilimler Enstitüsü, Ankara.

Sönmez, B. (2014). Kent yerleşimcilerinin turizm pazarlamasına yönelik tutumunu etkileyen faktörler: Erzurum İli Örneği. Yayımlanmamış Yüksek Lisans Tezi. Atatürk Üniversitesi Sosyal Bilimler Enstitüsü, Erzurum.

Şenel, Y. (2001). Turizm pazarlaması ve turizm sektöründe faaliyet gösteren işletmelerin karşılaşmış oldukları sorunlara ilişkin Nevşehir Bölgesi'nde bir uygulama. Yayımlanmamış Yüksek Lisans Tezi. Niğde Üniversitesi Sosyal Bilimler Enstitüsü, Niğde. 
Şimşek, A. T. (2008). Turizm pazarlamasında turistik tüketici davranışları açısından tatil satın alma sürecinin özellikleri ve Alanya üzerinde bir uygulama. Yayımlanmamış Yüksek Lisans Tezi. Marmara Üniversitesi Sosyal Bilimler Enstitüsü, İstanbul.

Todd, R. J. (2003). Adolescents of the information age: patterns of information seeking and use and implications for information professionals. School Libraries Worldwild, 9(2), 27-46.

Uçak, N. Ö. (1997). Bilgi Gereksinimi ve Bilgi Arama Davranışı. Türk Kütüphaneciliği, 11(4), 315325.

Ural, A. ve Kılıç, İ. (2006). Bilimsel Aştırma Süreci ve SPSS ile Veri Analiz, Ankara: Detay Yayıncılık. Uygur, S. M. (2007). Turizm Pazarlaması. Ankara: Nobel Yayın Dağıtım.

Westbrook, L. (1993). User needs: A synthesis and analysis of current theories fort the practitioner. Reference Quarterly, 32(Summer), 541-549.

Wilson, T. D. (2000). Human Information Behaviour. Special Issue on Information Science Research, 3(2), 49-55.

Yağcl, Ö. (2007). Turizm Ekonomisi. Ankara: Detay Yayıncllı.

Yalı, S. (2016). Kültürel turistlerin seyahat tercihleri ve yiyecek-içecek beklentileri: Safranbolu Örneği. Yayımlanmamış Yüksek Lisans Tezi, Karabük Üniversitesi Sosyal Bilimler Enstitüsü, Karabük.

Yılmaz, E. (2010). Marka imajının tüketici satın alma kararına etkisi ve alışveriş merkezlerine ilişkin bir araştırma. Doktora Tezi, İstanbul Üniversitesi Sosyal Bilimler Enstitüsü, İstanbul. 